\title{
Estimating short-run (SR) and long-run (LR) demand elasticities of phosphate
}

\author{
Rami Al Rawashdeh ${ }^{1}$
}

Received: 15 September 2021 / Accepted: 30 November 2021

(c) The Author(s), under exclusive licence to Springer-Verlag GmbH Germany, part of Springer Nature 2021

\begin{abstract}
Many empirical exercises estimating demand functions are concerned with estimating dynamic effects of price and income changes over time. Researchers are typically interested in getting estimates of both short-run (SR) and long-run (LR) elasticities, along with their standard errors. This study aimed to contribute with estimations of demand elasticities of world phosphate fertilisers. It answered the research question "How world demand of phosphate fertilisers is affected by its own price changes, cross price changes, income changes and other variables?". Short and long run elasticities are calculated using an economic model in this paper. The findings indicate that global phosphate demand is price inelastic both in the short and long run. In addition, in both the short and long run, income elasticity, cross price elasticity, and cross yield elasticity are inelastic. Our modeling predicts that phosphate consumption for fertilisers will increase from 45.35 million tons in 2018 to around 59.16 million tons by 2028; which implies that an average annual growth rate of $2.7 \%$ of P 2 O 5 will be required every year by phosphate consumers and that additional production capacity may be needed in order to meet this future demand. The results suggest that phosphate prices are forecast to increase, as long as demand continues to rise and no new production facilities are built.
\end{abstract}

Keywords Demand elasticity · Price elasticity $\cdot$ Income elasticity $\cdot$ Cross elasticity $\cdot$ Phosphate fertilisers $\cdot$ Price forecasting $\cdot$ Precision farming

\section{Introduction}

Phosphate, which is an essential element for the human body, occurs naturally in the form of phosphate rock that is processed to produce diammonium phosphate (DAP) and various fertilizer derivatives. Phosphate rock was first produced commercially in the UK in 1847 (Cathcart, 1980), and mining was almost certainly done by hand at the time. Mining of phosphate in the USA began in 1867 in South Carolina, where phosphate deposits were extracted manually and later by dredges (Shepard, 1880). According to Van Kauwenbergh (2010), phosphate rocks in Africa countries especially those in Algeria and Tunisia were

Rami Al Rawashdeh

r_rawash@yahoo.com.au

1 Department of Mining Engineering, College of Engineering, Al-Hussein Bin Talal University, Ma'an, Jordan discovered in the late nineteenth century, whereas phosphate rock production began in Morocco, the country with the world's greatest phosphate reserves, in the early and midtwentieth centuries. As US Geological Survey Data (various years) revealed, between the 1920s and 1950s, at least five countries extracted phosphate, and major companies were mainly operating in two nations - USA and Tunisia - which were jointly accounting for nearly $70 \%$ of the total production; however, in the latter half of the twentieth century, the geography of the industry has changed, and currently, firms based in China, Morocco, and Russia have emerged and have become major producers in the market.

The global market rivalry is intense and relatively integrated, with a small number of prominent competitors taking a significant portion of the total revenue in 2020 . Annual global production in 2020 reached to around 223 million tons, while estimated reserves stood at 71 billion tons (US Geological Survey, 2020). Using modern technologies, this figure indicates that the reserve may be drained 
Fig. 1 Major phosphate producers and their market share in 2020

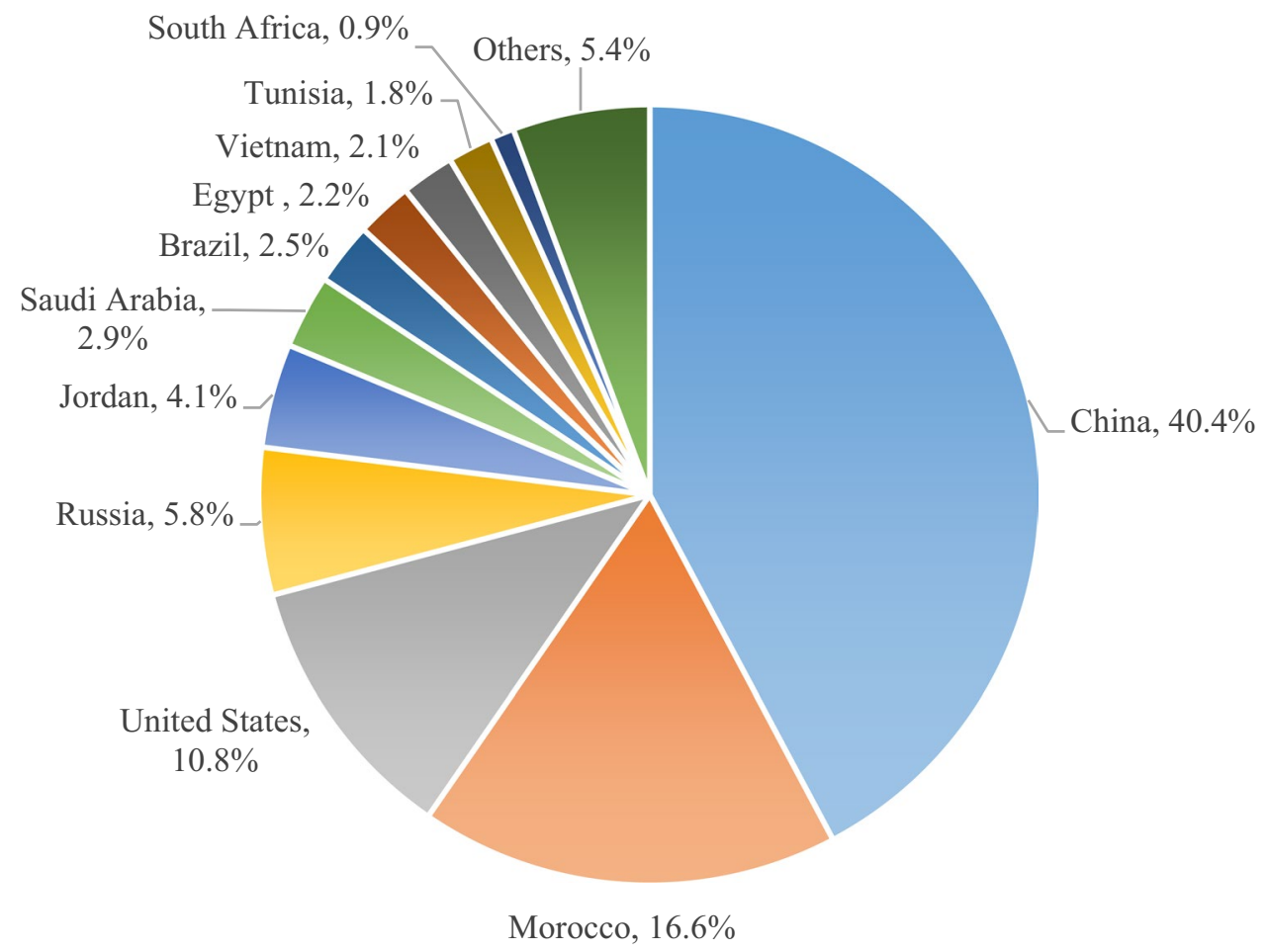

US Geological Survey (2021)

in roughly 318 years. ${ }^{1}$ The world's top producers in 2020 - many of them are government owned ${ }^{2}$ - include China (Yuntianhua Group), Morocco (Office Cherifien de Phosphate), the USA (Mosaic), and Russia (EuroChem). Figure 1 depicts the global phosphate output percentage shares by country in 2020 . China contributed to $40.4 \%$, followed by Morocco, ${ }^{3}$ the USA, Russia, Jordan, Saudi Arabia, and Brazil which accounted for $16.6 \%, 10.8 \%, 5.8 \%, 4.1 \%, 2.9 \%$, and $2.5 \%$, respectively.

As illustrated in Fig. 2, the most rapid expansion in phosphate consumption occurs from 1961 to 1988, when annual growth

\footnotetext{
1 As stressed by Mew (216) and Wellmer (2008), it seems generally accepted that (reserve/Ccnsumption) ratio of a commodity is not an indication of its lifetime. It is only a static figure in a dynamic system but can been regarded as an early warning indicator assuming that nothing related to resources use - including exploration efforts, technology development, population dynamics, or demand characteristics - changes.

2 According to Al Rawashdeh (2008), there has been a noteworthy trend in the recent years toward combining governmental and private ownership in the phosphate business. This approach delivers some of the benefits of public ownership while also providing the efficiency of private ownership.

${ }^{3}$ As the United States Geological Survey states, Morocco controls more than $70 \%$ of global phosphate rock reserves, which is why some analysts, such as Handfield (2012), predict Morocco's market share could reach up to $80-90 \%$ of global phosphate demand by 2030 . Unless additional primary supplies of phosphate can be obtained, the globe will grow increasingly reliant on one country for a crucial resource.
}

averaged more than 4.4 percent. Between 1988 and 1993, rock phosphate consumption dropped from 37.6 to 28.9 million tons, respectively; most likely was a consequence of political factors such as the collapse of the Soviet Union and decreased fertilizer demand from Western Europe and North America ${ }^{4}$ (Cordell et al., 2009). Nevertheless, consumption started to recover in the late 1990s and has continued to increase in the 2000s until it reached 37.7 million tons in 2007; it had then fallen to 32.8 million tons in 2008 due to the global financial crisis and continued rising after that due to rising economies such as China and India till 2019, when it hit 45.6 million tons.

The significance of this study arises from the fact that phosphate is regarded as a critical ${ }^{5}$ and crucial commodity on a global scale. Indeed, almost $90 \%$ of all phosphate mined is used in the manufacturing of fertilizers (Tirado \& Allsopp, 2012). An analysis of 362 seasons of crop output conducted by Stewart et al. (2005) found that commercial fertilizer

\footnotetext{
${ }^{4}$ As reported by Scholz et al (2013), developed countries that have the most efficient use of resources and higher environmental concern reached the peak of fertilizer consumption and the decline earlier than any other countries and that could be an additional reason for the sudden decline of phosphate consumption in the late eighties and early nineties.

5 While some institutions, such as Raw Material Information System (2020), consider phosphate to be a critical mineral, this is not due to limited reserves and resources; rather, as Mew (2016) reported, the implications of a PR supply-driven constraint are enormous, given the irreplaceable nature of $\mathrm{P}$ in biological processes.
} 


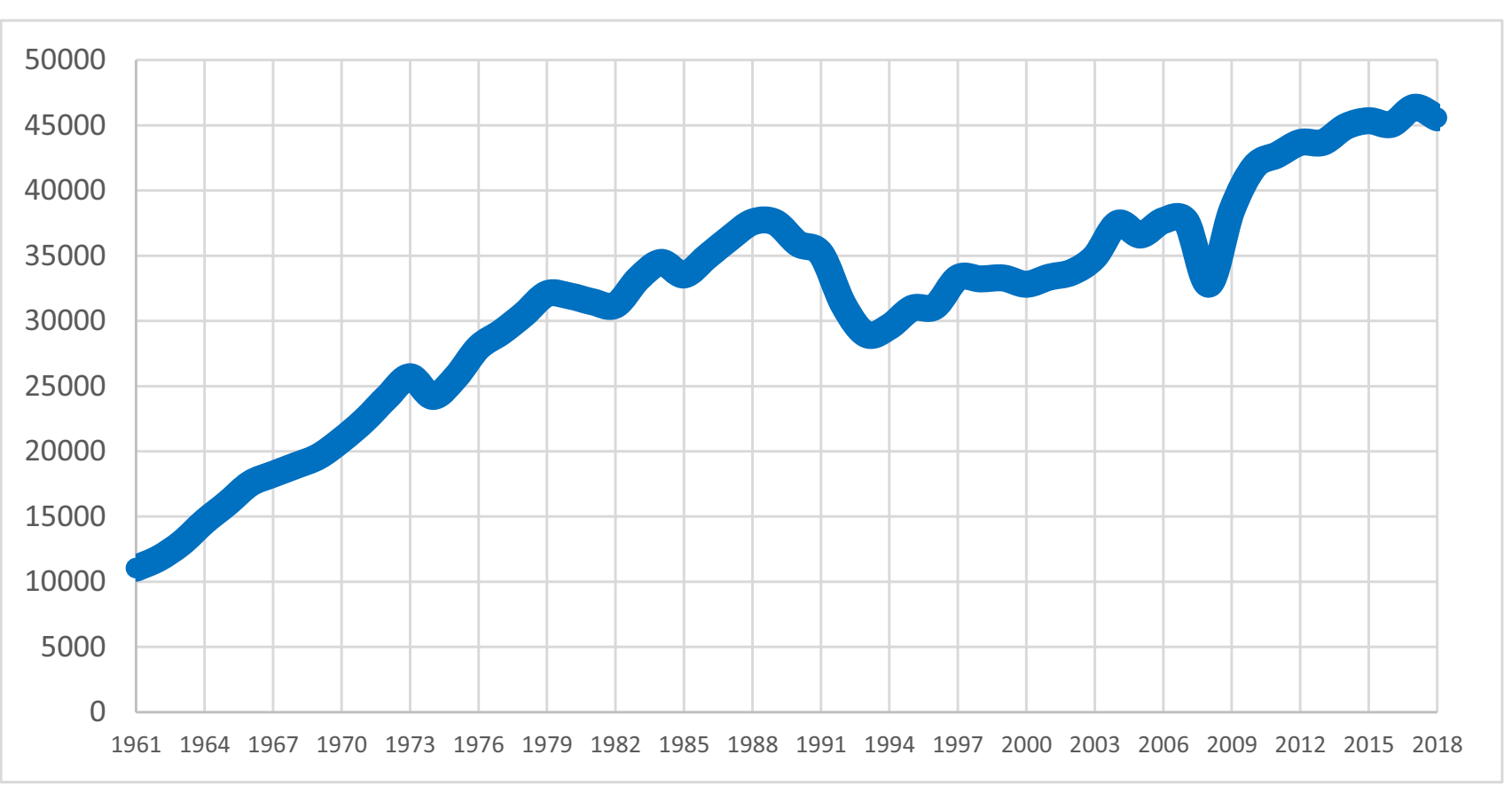

Fig. 2 Phosphate consumption (in $\mathrm{P}_{2} \mathrm{O}_{5}$ ) from 1961 to 2018

inputs are responsible for at least 40 to $60 \%$ of crop yield. If global population is anticipated to reach over 9.7 billion in 2050 (United Nations, 2019), it is critical to ensure that the fertilizers required to improve global food production are available. The Tomlinson (2013) study argued that in order to ensure that the world's population will be fed by the year 2050 , food output needs to expand by 70 to $100 \%$, and hence, most experts agree that, with genetics, biotechnology, and other inputs, the most important factor to consider is how to ensure a sufficient supply of phosphate fertilizer in order to boost harvest yields in the future.

The examination of the key elements influencing the phosphate market in the past has aroused the interest of an increasing number of analysts. Al Rawashdeh and Maxwell presented a paper in 2011 in which they explored in greater details the major factors affecting phosphate demand and supply. Several authors like Geissler et al. (2019), Mew et al. (2018), Manning (2015), and Horn and Sartorius (2009) have also made significant contributions to the literature. Although phosphate is relatively a cheap product with each person in the world consuming around \$US 6 of rock phosphate every year (Scholz et al., 2013), many impoverished farmers around the world are unable to enter the phosphate fertilizer market due to low purchasing power or insufficient funding. Indeed, many empirical studies of demand functions focus on the dynamic implications of price, income, or technology changes over time in order to derive demand elasticities that measure the degree to which individuals and consumers change their demand in response to price, income, or technology changes. For example, as Ridder et al. (2012) asserted, the sudden price surge in 2007 weakened the purchasing power of poor farmers, limiting their access to fertilizers; this resulted in a decrease in overall demand for phosphate fertilizers from 37.8 to 32.8 million tons (see Fig. 2).

The consequences of economic circumstances such as declining income in a recession or substantial rises in energy or fertilizer costs can be predicted using elasticity estimates generated with data acquired under normal market conditions. Given, for example, the income elasticity of demand, one can forecast the amount of consumption growth that will occur in response to an increase in income. For instance, if the income elasticity is 0.3 , which is inelastic, and income increases by $1 \%$, consumption should increase by less than $1 \%(\sim 0.3 \%)$. This suggests that if baseline consumption was 1000 units, a $1 \%$ rise in income would likely raise consumption to 1003 units $(1000+1000 * 0.3 \%)$. Production mainly depends on consumer demand, and care should be taken to adjust it to the extent of demand. Hence, elasticity is a concept which enables all producers to take correct decision regarding the quantum of output based on the demand, a knowledge of the elasticity of demand helps the governments and market players in formulating their plans and policies in cases of price, income, and technology changes.

Upon this brief introduction, this paper attempts to answer the question "How would global phosphate demand be affected by changes in its own price, cross price, income, and other factors that may affect it?" The goal of this study 
is to identify the major determinants of phosphate demand; to estimate price, income, and cross elasticities; and to forecast future phosphate consumption. To determine short- and long-run elasticities, the study typically employs a comprehensive econometric model. The first section has already introduced the paper. The second section provides a literature review on the various factors affecting fertilizers demand in general and discusses previous studies that have estimated demand elasticities related to different types of fertilizers. The third section discusses the demand function and specifies the main variables used in our model. It also examines the major tests (e.g., stationarity, cointegration, lag selection and weak exogeneity) required in order to reach to an appropriate estimation of the model. In section four, with reference to the error correction model (ECM), longand short-run elasticities results have been discussed, and a forecasting model has been utilized to project phosphate consumption and prices for the next decade. The final section concludes the paper with some comments.

\section{Literature review}

Studies on fertilizer demand, such as those by Chianu and Tsujii (2004), Croppenstedt and Demeke (1996), Zhou et al. (2010), and Maganga et al. (2011) have revealed that the primary causes of low fertilizer demand are inadequate revenues and low production levels, as well as lack of access to financial resources. Randive et al. (2021) reported that the limited geological resources of raw material for the manufacture of fertilizers and market fluctuations of fertilizer minerals initiate wide-reaching competition and raise challenge of food security. Previous research papers, such as those conducted by Hsu (1972), analyzed the impact of prices on the demand for fertilizers in Taiwan and concluded that fertilizer prices have a big impact on nitrogen demand, and less impact on phosphate and potash demand. Quddus et al. (2008) argued that while demand for nitrogen and phosphate fertilizers in Pakistan is inelastic, demand for potash fertilizer is elastic (Quddus et al, 2008). Furthermore, they found that the time variable employed to quantify the progress in technology had a large significant positive effect on fertilizer consumption. Rayner and Cooper (1994) employed appropriate error correction models to come to the conclusion that nitrogen's short- and long-run price elasticities were both quite low. Al Rawashdeh et al. (2016) developed an econometric model to evaluate short- and long-term demand elasticities for potash fertilizers. They discovered that potash demand is price, income, and cross price inelastic in both short and long term.

The study by Zhou et al. (2010) demonstrated that fertilizer's use in Northern China is heavily influenced by crop output and overall revenues. Their findings also showed that the area of the land, soil fertility, and the cost of delivery all had an inverse relationship with the amount of fertilizer used. According to Likoya and Mangisoni (2006), who examined the factors that drive the demand for fertilizers in Malawi, the main factors affecting demand in their study are fertilizers prices, loans access, food production index, and farm size. As Williamson (2010) observed, most industrialized countries' fertilizer consumption is price inelastic, but recently, farmers' response to rising fertilizer prices has become more sensitive. Griliches (1958) and Gunjal et al. (1980) both reported that the demand for fertilizers for grain is more responsive to price than cash crops. On the other hand, the influence of income on the cash crop model is large, while that of wheat and soybean models is negligible.

Socioeconomic factors, market access, information, and agricultural characteristics (e.g., soil fertility; irrigation) can influence farmers' use of inorganic fertilizers (Shrestha et al., 2013; Fishman et al., 2016; Kpadonou et al., 2019; Ward et al., 2019). A study by Acheampong and Dicks (2012) concluded that increased global demand for fertilizers is the result of global population and general economic growth. Enk et al. (2011) and Steiner et al. (2019) have noted that the main drivers of phosphate demand include population growth, increased food demand, increasing economic wealth, modifications in dietary habits, and increasing need for biofuels. Nygards and Svenungsson (2020) estimated phosphate fertilizer demand function in Sweden and found that, by including total harvest area variable or arable land variable in their econometric model, both would have a significant statistical positive impact on fertilizers consumption. Parthasarathy (1994) claimed that rainfall distribution over time is a fundamental predictor of fertilizer usage, and the greater the threat of adverse weather, the more farmers are reluctant to use fertilizers even if the cost-benefit analysis is favorable. Gruyter (2020) discovered that fertilizer use in Rwanda is dependent on various parameters relating to market access, financial liquidity, household assets, human resources, and extension services.

\section{Econometric analysis}

\section{General view of the model}

Tilton (1992) published a seminal work in which he listed the most critical parameters influencing minerals demand. The general form of the demand function is presented in Eq. 1.

Demanded quantity of phosphate $=f$ (real price of phosphate, real prices of complementary/substitute products, real income, technological progress, other variables) (1).

A mineral's own price is usually an important determinant of its demand, with demand tending to fall as price rises. Recall that, in general, if the price of a product increases, buyers will purchase less of it, all other factors being equal. 
In other words, if the price increases, the quantity demanded decreases; if the price decreases, the quantity demanded increases. This is the law of demand; it denotes that if the price of a product rises, there will be a leftward movement along its demand curve, and vice versa. Because there are no alternatives or substitutes for phosphate in its predominant usage (US Geological Survey, 2021), this expression in Eq. 1 does not account for any substitute minerals' price. In addition, nitrogen and potash fertilizers, which are also essential for plant growth, are complementary products. According to al Rawashdeh and Maxwell (2014), changes in income are directly tied to mineral demand. Mineral consumption tends to rise over long periods as real incomes rise. Mineral demand ${ }^{6}$ moves more closely with the business cycle over shorter time periods; it is high during economic expansions but low during recessions. Historical data on phosphate prices, the price of its complementary products (e.g., potash fertilizers), and world income are widely accessible.

In order to catch the technology variable, crop yield (cereal yield per hectare), which measures the quantity of agricultural output produced per unit of land area, can be used. Many scientific investigations have proven the positive influence of phosphate fertilizer applications on agriculture quality and yields. Tilman et al. (2011) evaluated how breakthroughs in technology could boost agricultural yields and then utilized his estimates to forecast demand for crops. Gordon (1998) note that the Green Revolution, which they claimed was connected with a more sophisticated application of fertilizers, was substantially responsible for the ability of formerly less fertile land to support increased food production. Pei and Tilton (1999) and Stuermer (2014) have both employed time variables instead to gauge the effects of changing technology on mineral demand, but as Scot (1964) reported, a time variable may imply that a continuous function represents a change in technology, and it is doubtful that development of technology follows a continuous function; therefore, the use of a time variable to represent change in technology is not wholly satisfactory.

Dummy variables can be included in the empirical analysis to reflect big shocks in the phosphate market, such as the break up of Soviet Union (USSR) in 1989 to1990 or the last world economic crisis of 2007-2008. Other variables like world population have not been included into our model; currently, the global population is above 7 billion, compared to the 2.5 billion people in 1950 . Recent estimates by the United Nations (2019) indicate that it will grow to 9.7 billion by the year 2050. There is a strong tendency for real GDP

\footnotetext{
${ }^{6}$ When it comes to mineral functions in general, each mineral has a certain purpose that can be met by another mineral (or with another technology); fertilizer minerals, on the other hand, are unique in that they are absolutely necessary for life and cannot be replaced or substituted (Schebek \& Becker, 2014).
}

and population ${ }^{7}$ to be closely related (Mankiw (2010), Sibe et al. (2016). This presents a problem with setting up an empirical model that has both variables present; therefore, (GDP/population (GDP per capita)) may be a more realistic alternative. Total calorie food intake can also be measured as a proxy for food consumption (Matthews \& Hammond, 1999), because as food consumption increases, demand for phosphate fertilizers increases. However, the World Health Organization (2014) and Fukase and Martin (2020) discovered substantial levels of collinearity between total calorie food intake and world real GDP estimations. Based on the findings of Tilman et al. (2011), an effective method for forecasting global crop demand entails using real per capita income as a proxy without taking into account other variables such as population or agricultural calorie intake.

\section{Specifications of the model}

We can infer from the demand components outlined above that the demand for phosphate $(Q)$ can be written in the following form:

$Q_{t}=\beta_{0}+\beta_{1} P_{t}+\beta_{2} Y_{t}+\beta_{3} H_{t}+\beta_{4} X_{t}$

where $P$ is phosphate real prices, $Y$ is per capita real income, $H$ is cereal yield, and $X$ is the explanatory variables; the subscript for $t$ ranges from 1961 to 2018, the intercept is set to $\beta_{0}$, and the other coefficients for other independent variables are set as $\beta_{1}, \beta_{2} \beta_{3} \beta_{4}$.

Consideration of both short- and long-run elasticities is beneficial for estimating such a model. The procedure presented by Cuddington and Dagher (2015) will be used in our methodology, and it is appropriate to include lagged variables in our model because demand functions for the majority of commodities display serially correlated errors. Our model will estimate the auto regressive distributed lag (ADL) shown in Eq. (2), with the standard lag selection approach of AIC being employed.

$$
\begin{aligned}
Q_{t}= & \beta_{0}+\sum_{l=1}^{L} \beta_{q l} Q_{t-1}+\sum_{l=1}^{L} \\
& \left(\beta_{p l} P_{t-l}+\beta_{y l} Y_{t-l}+\beta_{h l} H_{t-l}+\beta_{x l} X_{t-l}\right)+\varepsilon_{t}
\end{aligned}
$$

Once ADL is re-estimated, error correction model (ECM) will be produced in Eq. (3). ECM is regarded as completely efficient only when long-run elasticities are exogenously weak:

$$
\begin{aligned}
\Delta Q_{t} & =\alpha_{0}+\sum_{l=1}^{L-1} \alpha_{q l} \Delta Q_{t-l}+\sum_{l=0}^{L-1}\left(\alpha_{p l} \Delta P_{t-l}+\alpha_{y l} \Delta Y_{t-l}+\alpha_{h l} \Delta H_{t-l}+\alpha_{x l} \Delta X_{t-l}\right) \\
& +\eta\left(Q_{t-1}-\gamma_{p} P_{t-1}-\gamma_{y} Y_{t-1}-\gamma_{h} H_{t-1}-\gamma_{x} X_{t-1}\right)+\omega_{t}
\end{aligned}
$$

\footnotetext{
7 We have added logarithm of population to the empirical model, but results did not make sense as a result of high multicollinearity $(\sim 95 \%)$ between world population and real GDP per capita. Even when population growth is included, the same poor results are obtained.
} 


\section{$\mathbf{Y}, \mathbf{P}, \mathbf{C}, \mathrm{H}$}

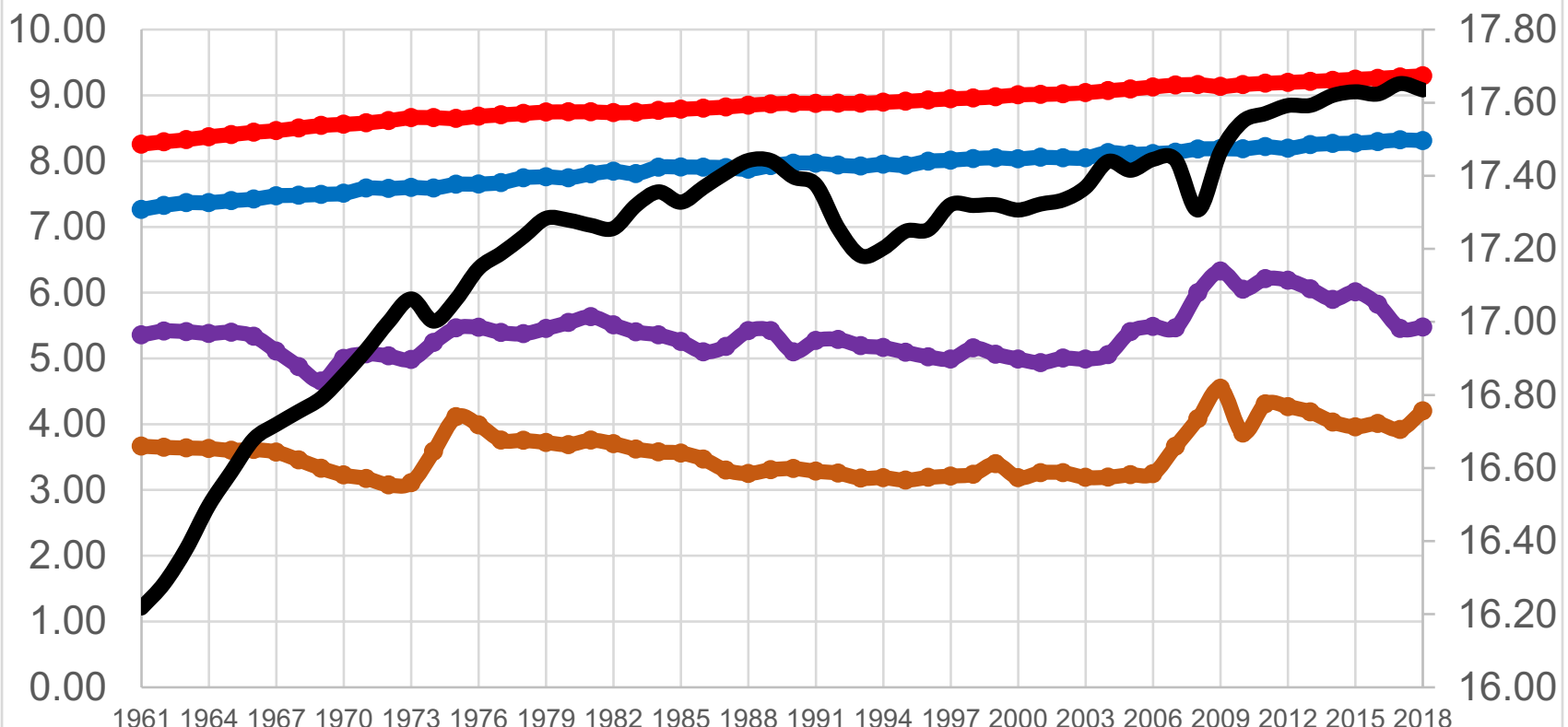

19611964196719701973197619791982198519881991199419972000200320062009201220152018

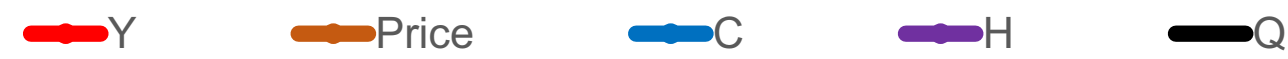

Fig. 3 Plot of logged data for all variables from 1961 to 2018

where $\eta$ is the parameter used to quantify the speed of adjustment to equilibrium, and $\Delta$ denotes the first-difference estimators. The $\eta \gamma$ represents the long-run elasticities, whereas the $\alpha$ 's represent short-run elasticities.

\section{Data and variables description}

Our sample spans the years from 1961 to 2018 , and the data used in our model were compiled from a number of different sources. The major variables are described as the following:

- $Q$ : The yearly phosphate fertilizer consumption obtained from International Fertiliser Association Statistics (2021)

- $Y$ : The estimated average GDP per capita for the world countries in 2010 \$US (Y), gathered from World Bank (2021)

- $\boldsymbol{P}$ : The real average annual price per ton phosphorus pentoxide $\left(\mathrm{P}_{2} \mathrm{O}_{5}\right)$ obtained from US Geological Survey (2021)

- $\boldsymbol{H}$ : The real average annual price per ton of potassium oxide $\left(\mathrm{K}_{2} \mathrm{O}\right)$ extracted from US Geological Survey (2021)
- $\quad \boldsymbol{X}$ : This includes additional variables such cereal yield $(\mathrm{kg}$ per hectare) which is used as a measure of technology. The World Bank (2021) provides data for this variable.

Natural logs of the raw data for all variables have been plotted in Fig. 3. Additionally, dummy variables ${ }^{8}$ have also been added; a dummy variable denoted by the letter $(\mathbf{M})$ was used to represent the unfavorable economic conditions that occurred in the years leading up to the dissolution of the USSR in 1988. The 2008-2010's global financial crisis was also represented with a dummy variable designated by the letter (S).

To better grasp the phosphate market, certain additional variables were taken into consideration, however, when they were added to the model, the results did not fulfill the standards of the weak exogeneity test. The variables in question were as follows:

- Annual real price of urea fertilizers, as a complementary products derived from International Fertiliser Association Statistics (2021)

\footnotetext{
8 These dummy variables will be added to the modified Eqs. 3 and 4 and will be used later in Eq. 5 .
} 
- Livestock units per county area, which accounts for fecal excretion and manure generation by many animals as a substitute for chemical phosphorus FAO (2020)

- Agricultural machinery per hectare of arable land, as technology measure (e.g., no. of tractors per 100 square kilometers arable land) (World Bank, 2021)

- Natural disasters (e.g., droughts, floods) (World Bank, 2021)

\section{Major tests of the model}

\section{Unit root test and lag selection tests}

In order for econometric models to yield conclusive and unequivocal regressions, time series variables must be stationary (Granger and Newbold, 1974). The current study will employ the Augmented Dickey-Fuller (ADF) (Dickey and Fuller, 1981) and Phillips-Perron (PP) tests (Phillips and Perron, 1988) to discover whether the variables in the model have unit roots or not. As for the lag selection criterion, in general, adding too many lags increases the standard errors of coefficient estimates, implying an increase in forecast error, but omitting necessary lags may result in estimation bias. In order to get the appropriate lag numbers, we will use the Akaike information criterion (AIC). We permit up to four lags and include a constant owing to the Q trend from 1961 to 2018.

\section{Cointegration and weak exogeneity tests}

Cointegration can be detected by employing Johansen's multivariate vector error correction (VEC) approach (Johansen, 1988). This approach uses the trace statistics and the Eigen value maximum statistics to determine cointegration. Following Cuddington and Dagher (2015), when estimating the ECM version of the ADL model, we use the most comprehensive model with weakly exogenous variables. To do so, we constrain our specification in the following ways: $\eta_{\mathrm{q}}=1, \eta_{\mathrm{p}}=0, \eta_{\mathrm{y}}=0, \eta_{\mathrm{h}}=0$, and $\eta_{\mathrm{c}}=0$, which can be set in Eviews 10 as, B $(1,1)=1, \mathrm{~A}(2,1)=0$, $\mathrm{A}(3,1)=0, \mathrm{~A}(4,1)=0$, and $\mathrm{A}(5,1)=0$.

\section{Results and discussion}

\section{Tests results}

To examine for unit root, implementing the usual ADF test was the next step in the process. As seen in Table 1, with the exception of $\mathrm{Q}$, all parameters used in our model
Table 1 Unit root testing by Dickey-Fuller and Phillips-Perron

\begin{tabular}{|c|c|c|c|c|}
\hline \multirow[b]{2}{*}{ Series } & \multirow[b]{2}{*}{ ADF $t$ statistics } & \multicolumn{3}{|c|}{$\begin{array}{l}\text { Interpolated Dickey-Fuller critical } \\
\text { values levels }\end{array}$} \\
\hline & & $1 \%$ & $5 \%$ & $10 \%$ \\
\hline Q & $-3.61 * * *$ & -3.57 & -2.93 & -2.60 \\
\hline $\mathrm{P}$ & -2.10 & -3.57 & -2.93 & -2.60 \\
\hline$\Delta \mathrm{P}$ & $-5.12 * * *$ & -3.57 & -2.93 & -2.60 \\
\hline Y & -1.81 & -3.57 & -2.93 & -2.60 \\
\hline$\Delta \mathrm{Y}$ & $-4.98 * * *$ & -3.57 & -2.93 & -2.60 \\
\hline $\mathrm{H}$ & -2.06 & -3.57 & -2.93 & -2.60 \\
\hline$\Delta \mathrm{H}$ & $-6.04 * * *$ & -3.57 & -2.93 & -2.60 \\
\hline $\mathrm{C}$ & -1.81 & -3.57 & -2.93 & -2.60 \\
\hline \multirow[t]{2}{*}{$\Delta \mathrm{C}$} & $-7.70 * * *$ & -3.57 & -2.93 & -2.60 \\
\hline & & \multicolumn{3}{|c|}{$\begin{array}{l}\text { Phillips-Perron test critical values } \\
\text { levels }\end{array}$} \\
\hline Series & PPerron t statistics & $1 \%$ & $5 \%$ & $10 \%$ \\
\hline Q & $-3.20^{*}$ & -4.14 & -3.49 & -3.18 \\
\hline$\Delta \mathrm{Q}$ & -6.09 & -4.14 & -3.49 & -3.18 \\
\hline $\mathrm{P}$ & -2.27 & -4.14 & -3.49 & -3.18 \\
\hline$\Delta \mathrm{P}$ & $-4.23 * * *$ & -4.14 & -3.49 & -3.18 \\
\hline Y & -3.48 & -4.14 & -3.49 & -3.18 \\
\hline$\Delta \mathrm{Y}$ & $-5.30 * * *$ & -4.14 & -3.49 & -3.18 \\
\hline $\mathrm{H}$ & -2.12 & -4.14 & -3.49 & -3.18 \\
\hline$\Delta \mathrm{H}$ & $-6.40 * * *$ & -4.14 & -3.49 & -3.18 \\
\hline $\mathrm{C}$ & -3.02 & -4.14 & -3.49 & -3.18 \\
\hline$\Delta \mathrm{C}$ & $-10.40 * * *$ & -4.14 & -3.49 & -3.18 \\
\hline
\end{tabular}

Significance levels expressed as 99\%***; 95\%**, and 90\%*

are non-stationary in levels at the $90 \%, 95 \%$, and $99 \%$ confidence levels, but when analyzed as first-differences, they become stationary. Likewise, Phillips-Perron test revealed that all variables are non-stationary in levels (with the exception of $Q$ at the $90 \%$ confidence level), but they become stationary when viewed as first differences at the $90 \%, 95 \%$, and $99 \%$ confidence levels. The AIC, with four other criteria (the LR, FPE, HQIC, and SBIC) is shown in Table 2, which lists the lag selection methods. In this model, the AIC selected a model with one lag. Furthermore, HQIC, SBIC, and FPE all went with a onelag model, while LR went with a three-lag approach. The results indicate that the appropriate choice is the inclusion of one lag in all variables in the model. Our investigation into cointegration proceeds from the lag determination, and the tests for the Johansen trace and maximum eigenvalue are employed, yielding results that favor a one cointegrating relationship, as seen in Table 3 .

Following the approach established by Urbain (1992) and Cuddington and Dagher, the Chi-square value of 6.87 with a probability of 0.1428 suggests that at the $95 \%$ confidence level, the weak exogeneity restrictions cannot be rejected, and thus, the ECM specification (Eq. 4) is fully efficient. 
Table 2 Lag selection methods

\begin{tabular}{lllllllll}
\hline Lag & $L L$ & $L R$ & $d f$ & $P$ & $F P E$ & $A I C$ & $H Q I C$ & SBIC \\
\hline 0 & 162.56 & & & & 0000 & -5.46 & -5.25 & -4.91 \\
1 & 446.73 & 568.33 & 25 & 0.000 & $0000^{*}$ & $-15.61^{*}$ & $-14.50^{*}$ & $-13.59^{*}$ \\
2 & 480.98 & 68.5 & 25 & 0.000 & 0000 & -15.40 & -14.48 & -13.01 \\
3 & 511.60 & $61.25^{*}$ & 25 & 0.000 & 0000 & -15.22 & -14.33 & -12.3 \\
4 & 526.10 & 29.00 & 25 & 0.265 & 0000 & -15.0 & -13.59 & -11.0 \\
\hline
\end{tabular}

Table 3 Results for Johansen cointegration test

\begin{tabular}{llllll}
\hline Rank & Eigenvalue & Trace statistic & $5 \%$ critical value & Max statistic & 5\% critical value \\
\hline None & - & 80.55 & 68.52 & 34.67 & 33.46 \\
1 & 0.45 & $45.87^{*}$ & 47.21 & $27.07^{*}$ & 27.26 \\
2 & 0.38 & 18.61 & 29.68 & 10.15 & 20.97 \\
3 & 0.16 & 8.46 & 15.41 & 6.93 & 14.07 \\
4 & 0.11 & 1.53 & 3.76 & 1.53 & 3.76 \\
5 & 0.02 & & & & \\
\hline
\end{tabular}

$\Delta Q_{t}=\alpha_{0}+\alpha_{p} \Delta P_{t}+\alpha_{y} \Delta Y_{t}+\alpha_{h} \Delta H_{t}+\alpha_{c} \Delta C_{t}+\eta\left(Q_{t-1}-\delta_{p} P_{t-1}-\delta_{y} Y_{t-1}-\delta_{h} H_{t-1}-\delta_{c} C_{t-1}\right)+\alpha_{r} M+\alpha_{f} S+\omega_{t}$

\section{Phosphate short-run and long-run elasticities}

We have summarized in Tables 4 and 5 the elasticity coefficients produced by our phosphate model for both the short and long terms. Directly from the ECM estimation, it is possible to obtain elasticities (in both short and long run), as well as their corresponding standard errors.

\section{Price elasticity}

Because all variables are defined using logged variables, the regression coefficients are understood as elasticities; a $1 \%$ change in an independent variable will result in a $1 \%$ change in the dependent variable (Perloff, 2014). Due to human necessity for food, it would seem that an increase or decrease in phosphate prices would have little immediate effect on its demand al Rawashdeh R. Maxwell P. (2011). The short-run and the long-run price elasticities of demand were estimated at $(-0.003)$ and $(-0.061)$, respectively, which indicates that in general terms, phosphate prices have an inelastic effect on demand $(0<|\varepsilon|<1)$. If the price of phosphate increases by $1 \%$, phosphate use in the world would decrease by $0.003 \%$ in the short run and by $0.061 \%$ in the long run. The results from this study indicate that phosphate fertilizers are inelastic goods and that the demand of phosphate will decrease less relative to a hypothetical price increase. This implies that farmers are not sensitive to phosphate fertilizer prices in both short and long runs and that any change in these prices would lead to insignificant changes in quantity demanded, which also means that policies that could affect fertilizer demand in the world are not likely to have serious impact on the growth of the agricultural sector in the world if the prices are not allowed to change drastically. These results coincide with results of Nygards and Svenungsson (2020) and Denbaly and Vroomen (1993) who found that price elasticities for phosphate tend to be inelastic.

Price elasticities of demand in the long run are larger than price elasticities of demand in the short run, as can be observed, since consumers have more time to respond to price changes by identifying more substitutes in the future (e.g., organic fertilizers). In general, as Howie (2006) argued, a considerable proportion of industrial minerals is utilized in the manufacturing of non-durable end products such as clays in animal feedstuffs, as well as phosphate in fertilizers, and so, the longer customers have to adjust to a price adjustment for non-durable end products, the greater the response to a price change will be. As a result, long-term demand for phosphate will be more price elastic than short-term demand.

The higher price inelasticity in the long run can also be related to the ability of soils to retain nutrients which means that a larger cut in fertilizers in the long run will not significantly affect soil productivity. Crowson (1998) asserted that although fertilizer application on a regular basis is required for optimal plant growth, delaying fertilizers application for one or two seasons can be done without significantly affecting crop yield. Crowson (2006) stated that when most phosphate producers increased prices significantly in the mid-1970s to emulate OPEC's success, farmers worldwide responded by lowering phosphate fertilizer demand. Mew (2016) reported that the ability of some soils to absorb a 
Table 4 Phosphate equivalent ECM results

\begin{tabular}{llll}
\hline Long run & Coeff & $S E$ & $P$-value \\
\hline $\ln (\mathrm{Q}(-1))$ & 1.000 & & \\
$\ln \mathrm{P}(-1)$ & $-0.061^{*}$ & 0.035 & 0.086 \\
$\ln \mathrm{Y}(-1)$ & 0.078 & 0.145 & 0.594 \\
$\ln \mathrm{H}(-1)$ & -0.019 & 0.035 & 0.589 \\
$\ln \mathrm{C}(-1)$ & -0.185 & 0.144 & 0.265 \\
ECM & Coeff & SE & P-value \\
Cointegrating Eq & $-0.126^{* * *}$ & 0.040 & 0.003 \\
Constant & $1.490^{* * *}$ & 0.418 & 0.001 \\
$\ln \Delta \mathrm{P}$ & -0.003 & 0.041 & 0.94 \\
$\ln \Delta \mathrm{Y}$ & 0.403 & 0.429 & 0.352 \\
$\ln \Delta \mathrm{H}$ & $-0.070^{* *}$ & 0.034 & 0.045 \\
$\ln \Delta \mathrm{C}$ & -0.162 & 0.184 & 0.320 \\
Dummies & & & \\
$\mathrm{M}$ & $-0.187^{* * *}$ & 0.042 & 0.000 \\
$\mathrm{~S}$ & $-0.072^{* *}$ & 0.029 & 0.019 \\
$R^{2}=0.600$ & & & \\
$\mathrm{~F}(11,45)=6.15$ & & & \\
$\operatorname{Prob}>\mathrm{F}=0.000$ & & & \\
\hline
\end{tabular}

Significance levels expressed as $99 \% * * * ; 95 \% * *$, and $90 \% *$

significant proportion of the applied soluble $\mathrm{P}$ as low-solubility compounds creates a P bank or "sink" in the soil that is released slowly over time as plant available $\mathrm{P}$, this mechanism allows farmers in many of the major grain growing regions such as Europe to lower, or remove all together, $\mathrm{P}$ applications for one or more seasons, without detriment to the crop yield. When farmers are pushed to do this by deteriorating economics, the demand for phosphate fertilizers and hence phosphate rocks can be substantially reduced. According to al Rawashdeh R. Maxwell P. (2011), a higher price elasticity in the long run means that farmers have realized that the use of heavy doses of fertilizer in the 1960s and 1970 s created a soil that retained nutrients. So, by the 1980s, the soil was rich enough that smaller doses of fertilizer were

Table 5 Demand elasticity estimates for phosphate in the short and long run

\begin{tabular}{lll}
\hline & \multicolumn{2}{l}{ Elasticities } \\
\cline { 2 - 3 } & $S R$ & $L R$ \\
\hline P (phosphate price) & -0.003 & -0.061 \\
Standard error & 0.041 & 0.035 \\
Y (real income) & 0.403 & 0.078 \\
Standard error & 0.429 & 0.145 \\
H (complementary price) & -0.070 & -0.019 \\
Standard error & 0.034 & 0.035 \\
C (cereal yield) & -0.162 & -0.185 \\
Standard error & 0.184 & 0.144 \\
\hline
\end{tabular}

sufficient to sustain fertility. This is also in agreement with Heckenmüller et al. (2014), who suggested that the overuse of phosphate fertilizers would enhance crop yields and soil's phosphate supply, which may be utilized by crops in subsequent years. Thus, over-application of phosphate fertilizers may be justified, particularly on phosphate-deficient soils. However, once attained, it is prudent to apply only the amount of phosphate required to maintain this essential level.

\section{Income elasticity}

According to Al Rawashdeh and Maxwell (2014), many people perceive an increase in their income, which frequently results in dietary shifts in their consumption, as they begin to purchase more packaged food goods, as well as more meat, dairy, and beverages from grocery stores. Demand for phosphate is income inelastic, as seen in Table 5 . It can be noticed, that short-term income elasticity of demand (0.403) is larger than the long-term income elasticity ${ }^{9}(0.078)$.

In fact, as people become wealthier, they tend to spend less on food and more on non-food products. While total food expenditures rise, the proportion of total income spent on food decreases, lowering demand for fertilizers; as people become wealthy and their caloric requirements on a daily basis are met, they begin to place a greater emphasis on the taste and quality of food rather than the quantity (Jensen and Miller, 2011; Skoufias et al., 2011). As a result, understanding the relationship between wealth and food consumption (and consequently phosphate fertilizer need) is crucial for creating policies targeted at combating malnutrition and enhancing food security in developing nations. Studies such as those conducted by Melo et al. (2015), who used a meta-analysis approach to explain the large heterogeneity in income elasticities across the African continent, concluded that the global relationship has exhibited a "trading up" phenomenon (in which individuals consume more high-quality protein foods as their income increases) and a "convergence" phenomenon (in which individuals consume less food over time as their spending habits of low income individuals change).This will, in the long run, lead to the higher reduction in the consumption of fertilizers as income increases.

\footnotetext{
${ }^{9}$ Metals, on the other hand, have a different explanation. Income elasticity of demand for metals (such as copper), according to Pei and Tilton (1999), is stronger in the short run (elasticity $>1$ ) than in the long run (elasticity 1). Demand for metals is expected to be income elastic in the short run, owing to the fact that metal prices are heavily influenced by fluctuations in the global business cycle, and that metals are heavily consumed by the machinery industry and other economic sectors whose output fluctuates significantly over the short run. However, they predicted that the income elasticity would be approximately one in the long run.
} 
A further explanation for the reduced long-run income elasticity can be found in the notion of "Intensity of Use" addressed by Fernandez (2018), Crowson (2018), and Guzmán et al. (2005). Crowson (2018) confirmed that the relationship between GDP per capita and consumption of aluminum, refined copper, and crude steel per unit of GDP in eight countries has an inverted $U$ shape. This means, as explained by Guzmán et al. (2005), that as development progresses, the industrial, construction, and other metal-intensive sectors expand, resulting in an increase in the intensity of metal consumption. When the need for new dwellings, roads, autos, and refrigerators reaches a certain level, the growth rate begins to slow, and consumer preferences begin to change toward services, computers, and other less metalintensive commodities. Therefore, as development proceeds, the intensity of use finally reaches a peak and then begins to decline. Thus, a classic inverted U-shaped curve may be applicable over the long term in the context of phosphate intensity and its relationship to economic development, with recent fertilizer usage remaining stable or declining in affluent countries, while rising at a faster or equal rate to real GDP growth in developing countries.

\section{Complementary prices and cereal yield elasticities}

Potash and phosphate ${ }^{10}$ are frequently applied precisely in order to suit the specific requirements of a certain crop, climate, soil type, or topographic feature. Fertilizers containing phosphate help plants form new roots, make seeds, fruit, and flowers, whereas potash helps plants make strong stems and keep them growing fast. In our results, we found that the complementary potash price elasticities in both short run and long run were low and negative, indicating that potash and phosphate are complementary products (not substitutes) and that a $1 \%$ rise in potash prices tends to decrease phosphate demand by $0.07 \%$ in the short run and $0.019 \%$ in the long run.

Regarding technological changes, cereal yield was used as the measuring factor. Following the argument of Strengers et al. (1999) with respect to metals, changes in requirements for minerals may also occur as a result of substitution ${ }^{11}$ and technological advancements, which may result in more effective raw material utilization in the manufacturing of finished goods. Our findings confirm that cereal yield is negatively signed with an elasticity of 0.162 in the short run and 0.185 in the long run. The results also show that, by

\footnotetext{
10 Nitrogen was added to the model, but the results did not fulfill the standards of the weak exogeneity test.

11 This is the difference to metals, that the fertilizer minerals $\mathrm{N}, \mathrm{P}$, and $\mathrm{K}$ cannot be substituted.
}

producing more cereals, the amount of fertilizer is decreased in the long term. New technology, including genetically modified seeds, GPS systems, and nutrition management programs, is being introduced into farming, according to Sohn (2006) and al Rawashdeh (2011), who discovered that this has resulted in increased efficiency when it comes to the use of all types of fertilizers. Planting low phosphate demanding crops by breeding specialized phosphate efficient species has been prioritized with the aid of new technologies (Richardson, 2009). Besides that, controlled-release fertilizers are part of a sustainable approach to agriculture known as "precision farming" approach which improves crop yield and minimizes excessive nutrient release by combining data analytics. Carbeck (2019) stated that this approach utilizes advanced sensor systems, as well as data analytics and artificial intelligence, to ascertain how much fertilizer is required by plants at any moment of time. Then, autonomous vehicles are used to deliver nutrients in prescribed amounts and locations, which would at the end increase crop yields and reduce excessive nutrient release. Bindraban et al. (2020) has argued that current breakthroughs in nanotechnology indicate an opportunity to decrease phosphate loss while enhancing plant efficiency. The application of nanotechnology, which utilizes materials in the nanoscale (less than $100 \mathrm{~nm}$ ), has been shown to improve the precision of phosphorus release rates to better fulfill crops demand and reduce phosphorus loss.

Starting in 2029, phosphorus recycling is mandatory for all German cities with populations above 50,000. This would enable a decrease in phosphate product imports of up to $40 \%$ (Deutsche Phosphor-Plattform, 2019). Not only technology, but new research ideas have been adopted by some countries in order to reduce phosphate fertilizers usage. For example, on 250,000 hectares in Goias (Brazil), "natural" nutrient sources have been used to enhance the soil using "po de rocha", which is created from native minerals rich in nutrients, which come from volcanic rocks (MAPA 2019).

\section{Forecasting measures and future prospects}

\section{Forecasted consumption}

Figure 4 illustrates the 10-year out of sample projections for all variables (with $95 \%$ confidence interval (CI), ${ }^{12}$ using the VECM version of Eq. 5. From the forecasts of $Q$, we can project phosphate consumption in the next decade. Remember that our model's parameters were in logarithmic form and so quantity of phosphate in million tons is equal to $e^{Q}$.

\footnotetext{
12 The confidence interval (CI) is a range of values that is likely to include a population value with a certain degree of confidence. It is often expressed as a \% whereby a population mean lies between an upper and lower interval.
} 
(a) Forecast for $Q$

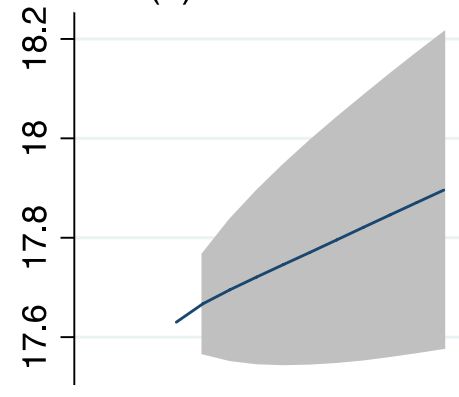

(d) Forecast for $\mathrm{H}$

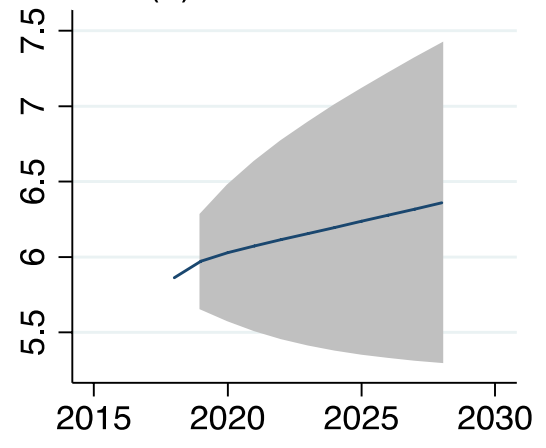

(b) Forecast for $Y$

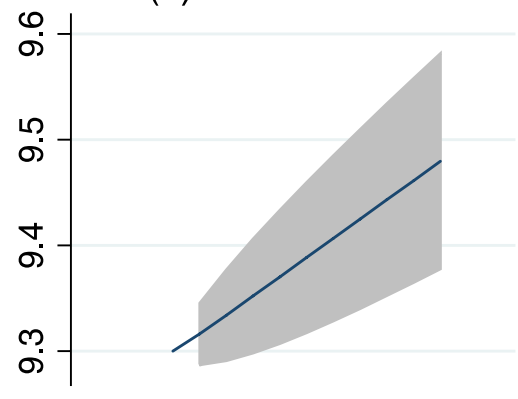

(e) Forecast for $\mathrm{P}$

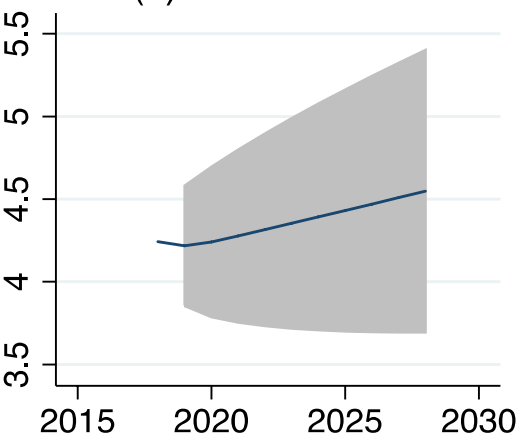

(c) Forecast for $\mathrm{C}$

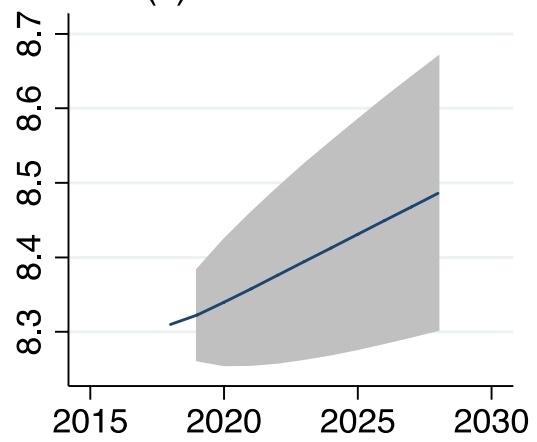

\section{$95 \% \mathrm{Cl}$ forecast}

Fig. 4 Log levels forecasts for key variables, Q, P, H, Y, and C

The results in Fig. 5 show that global phosphate consumption for fertilizers is predicted to rise from 45.35 million tons in 2018 to about 59.16 million tons in 2028, implying that phosphate consumption would grow at a rate of $2.7 \%$ per year. This also implies that phosphate users will require an additional 1.2 million tons of $\mathrm{P}_{2} \mathrm{O}_{5}$ on an annual basis and that producers would need to increase capacity to satisfy this demand.

This is pretty much in line with the Research and Markets Study (2020), which predicted that phosphate consumption will rise at a rate of $2.4 \%$ from 2020 to 2027 . The phosphate market, on the other hand, is anticipated to grow at a pace of $2 \%$ between 2020 and 2027, according to Data Bridge Market Report (2021). As Williams (2021) suggests, the global demand for phosphate is anticipated to climb in the next 5 years in tandem with the increase in world population. According to the FAO (2020), the agriculture sector's need for phosphate will continue to rise in the next few years due to:

As global nutrition patterns move toward higher levels of animal-sourced meals, there will be an increase in the number of crops and other agricultural and seafood products utilized as feed.

The increased income per capita for citizens in developing countries (i.e., China, India) and the dietary transition from vegetarian to meat and dairy-rich diets will drive up the demand for agricultural products, which will require additional acreage for cultivation and greater agriculture intensification, resulting in higher phosphate fertilizer use. The worldwide arable land area is limited due to the expansion of the world's population, urbanization, and the conversion of available land to residential uses.

In the future, the overall business strategy should be set to ensure that there is enough supply of phosphate in the world to meet the predicted demand at fair market prices. According to the US Geological Survey (2021), the majority of future production capacity increases are planned for Africa and the Middle East until 2024, with large expansion projects underway in Algeria, Egypt, Guinea Bissau, Morocco, Senegal, and Togo. A strategy for responding to global demand in the short term, bringing on significant 


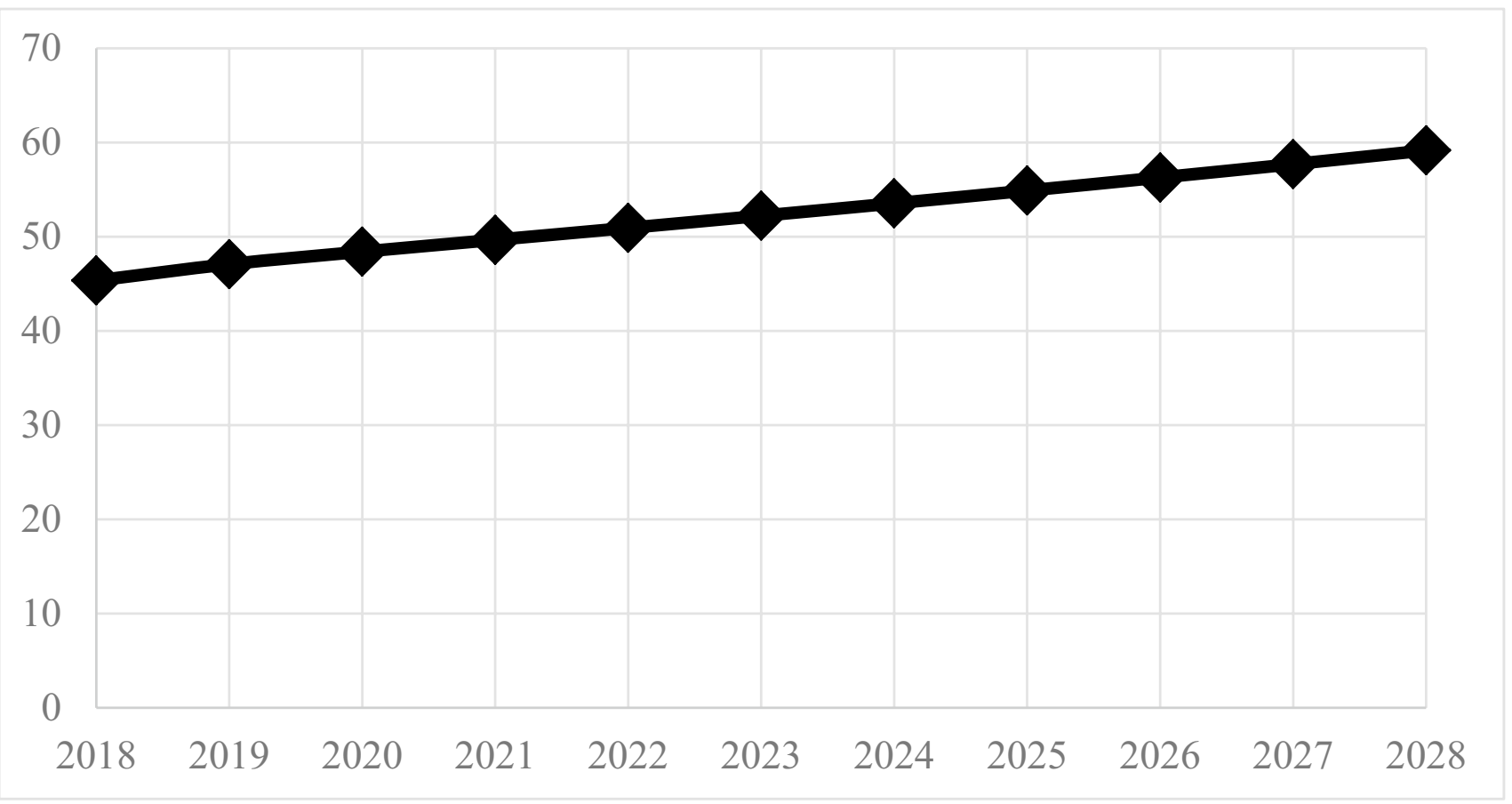

Fig. 5 Phosphate demand projections (in million tons) from 2018 to 2028

existing excess capacity, is more cost effective than building a new one (e.g., greenfield projects). Therefore, the capacity increase will likely be from a combination of new mines and expansions of existing operations.

\section{Forecasted prices}

In light of the supply and demand variables, as can be seen in Fig. $4 \mathrm{e}$ above, prices for phosphate are expected to increase in the next 10 years. Due to the fact that there are no substitutes or replacements for its primary purpose as a fertilizer, phosphate prices will continue to climb as long as demand increases, and no additional capacity is put in place. Recent corona virus pandemic crisis has caused a high rise in phosphate prices in recent years, which has pushed prices for food to high levels (Dietsch, 2021). As Bloomberg (2021) reported, this is majorly due to the restrictions on import and export, movement of people and goods across various countries in the world, and delays and disruptions in supply chain. Oxford Analytica (2020) confirmed the high boost in phosphate prices in the coming years and reported that the Chinese phosphate production, around one-third of which is concentrated in Hubei province, has been hit hard by the COVID-19 outbreak, and so, reduced Chinese exports in the coming years combined with US and Indian inventories being drawn down will likely push up phosphate fertilizers prices in the coming few years. If the price of phosphate fertilizers remains high for the foreseeable future, existing companies with high costs will be able to maintain their viability; this will increase producers' current net phosphate production capacity and will enable them to bring greater vertical integration with fertilizer producers, enhance local value-added, undertake maintenance and modernizations of production processes, improve foreign revenues, and create employment opportunities.

To the contrary of the previously stated viewpoint, it is crucial to note that if the price of phosphate remains high for an extended period of time, new manufacturers will enter the market, adding additional capacity to the existing ones, finally resulting in a fall in the price of the commodity. In the same way, as time goes on, any sustained price increase will, according to Data Bridge Market Report (2021), encourage further investment in the discovery and exploitation of new alternatives, finally driving prices down. Furthermore, new technological advances in the industry and the development of environmentally friendly and innovative low-cost crop nutrients will be a major factor among other factors that will act as a restraint on the growth of the phosphate market during the forecast period mentioned above. Van Kauwenbergh (2010) reported that efforts are needed to more effectively mine and process reserves/resources of phosphate rock and to utilize phosphate fertilizer and phosphate-containing waste as efficiently as possible. Keeping nutrients out of watersheds and the oceans is most desirable. All of these efforts must be tempered and explored realizing that only 
those techniques or processes that are logistically, technically and economically feasible are likely to be adopted.

\section{Conclusion}

Short-run (SR) and long-run (LR) elasticities, as well as their respective standard errors, are of interest to most researchers. Governments and industry officials would be eager to learn how a potential own or complementary price, income, or cereal increase would affect the phosphate demand in the short run and long run. This study aimed to contribute with estimations of demand elasticities of world phosphate fertilizers. It answered the research question "How world demand of phosphate fertilizers is affected by its own price changes, cross price changes, income changes and cereal yield changes?" To generate the most accurate estimations possible, the study employs ECM version of the ADL model, that considers weakly exogenous parameters when estimating both short- and long-run elasticities. As the results show, phosphate demand is inelastic and insensitive to its own pricing, the prices of its complements, world per capita income, and crop yield fluctuations over the short run and long term.

Based on an investigation looking to the future, it was projected that worldwide phosphate fertilizer consumption and prices will both climb through 2028. The prediction from our models shows that the consumption of phosphate would rise from 45.35 million tons in 2018 to roughly 59.16 million tons by 2028 . This means that phosphate consumption growth will be roughly $2.7 \%$ annually for the next decade. This means that, on average, phosphate consumers will need an additional 1.2 million tons of $\mathrm{P}_{2} \mathrm{O}_{5}$ per year, and therefore, to accommodate this demand, it is probable that extra capacity will be required. According to our findings, phosphate prices are forecast to increase, as long as demand continues to rise and no new production facilities are built. It is also possible that future lower quality reserves would raise processing costs, leading to a price increase for both mining and ore. However, since modern food production relies heavily on phosphate, in countries where the domestic agricultural sector struggles to feed its people, efficient phosphate application could assist in reducing the need for food imports by allowing farmers to increase their food productivity, which in turn would increase their livelihoods and keep their daily diet secure.

Acknowledgements I would like to express my gratitude to John Tilton for his insightful remarks on an earlier draft of this paper.

\section{Declarations}

Conflict of interest/Competing interests The author declares no competing of interests.

\section{References}

Acheampong, K. Dicks, M. (2012). Fertilizer demand for biofuel and cereal crop production in the United States. Southern Agricultural Economics Association Annual Meeting, Birmingham, Alabama, February 4-7, 2012.

Al Rawashdeh R (2008) The supply behavior of state mining enterprises: a case study of the Jordanian phosphate industry. Resour Policy 33(2008): 196-202

al Rawashdeh, R. Maxwell, P. (2011) The evolution and prospects of the phosphate industry. Miner Econ 24:15-27

Al Rawashdeh R, Maxwell P (2014) Analysing the world potash industry. Resour Policy 41(2014):143-151

Al Rawashdeh R, Xavier-Oliveira E, Maxwell P (2016) The potash market and its future prospects. Resour Policy 47(2016):154-163

Bindraban P, Dimkpa C, Pandey R (2020) Exploring phosphorus fertilizers and fertilization strategies for improved human and environmental health. Biol Fertil Soils 56:299-317

Bloomberg. (2021). Global fertilizer market to generate $\$ 323,375.0$ million and exhibit a CAGR of 5.0\% from 2021 to 2028. https:// www.bloomberg.com/press-releases/2021-08-25/global-fertilizermarket-to-generate-323-375-0-million-and-exhibit-a-cagr-of-5-0from-2021-to-2028-exclusive-report-225

Carbeck, J. (2019). Smarter fertilizers can reduce environmental contamination. https://www.scientificamerican.com/article/smarterfertilizers-can-reduce-environmental-contamination/

Cathcart, J. (1980). World phosphate reserves and resources, IN The Role of Phosphorus in Agriculture, pp. 1-18, Madison, Wisconsin.

Chianu J, Tsujii H (2004) Determinants of farmers' decision to adopt or not adopt inorganic fertilizer in the savannas of northern Nigeria. Nutr Cycl Agroecosyst 70(1):293-301

Cordell D, Drangert J, White S (2009) The story of phosphorus: global food security and food for thought. Glob Environ Chang 19(2009):292-305

Croppenstedt, A., Demeke, M. (1996). Determinants of adoption and levels of demand for fertilizer for cereal growing farmers in Ethiopia. Working Paper No. 96-3, Centre for the Study of African Economies, Oxford University Institute of Economics and Statistics, Oxford.

Crowson, P, 1998. Inside mining: the economics of the supply and demand of minerals and metals(Mining Journal Books: London).

Crowson P (2006) Minerals markets, prices and the recent performance of the minerals and energy sector. In: Maxwell P, Guj P (eds) Australian mineral economics. Australian Institute of Mining and Metallurgy, Melbourne

Crowson P (2018) Intensity of Use Reexamined Miner Econ 31:61-70

Cuddington J, Dagher L (2015) Estimating short and long-run demand elasticities: a primer with energy-sector applications. Energy J 36(1),185-209

Data Bridge Market Research. (2020). Global phosphate market industry trends and forecast to 2027. https://www.databridge marketresearch.com/reports/global-phosphate-market

Denbaly M, Vroomen H (1993) Dynamic fertilizer nutrient demands for corn: a cointegrated and error-correcting system. Am J Agr Econ 75(1):203-209

Deutsche Phosphor-Plattform (2019): The most frequently asked questions from citizens and decision maker on the subject of phosphorus recycling. https://www.deutsche-phosphor-plattform.de/ wp-content/uploads/2019/02/FAQs-zur-Phosphorr\%C3\%Bcckg ewinnung.pdf

Dickey D, Fuller W (1981) Likelihood ratio statistics for autoregressive time series with unit root. Econometrica 49(4):1057-1072

Dietsch, M. (2021). Fertilizer demand remains strong. https://www. farmweeknow.com/profitability/fertilizer-demand-remains-strong/ article_a79bdca4-f93b-11eb-b13a-9b5a90eed50b.html 
Enk, R., Vee, G., Acera, L., Schuiling, R., Ehlert, P. (2011). The phosphate balance: current developments and future outlook. Innovation Network, Utrecht. https://research.wur.nl/en/publications/ the-phosphate-balance-current-developments-and-future-outlook

FAO. (2020). Livestock patterns. http://www.fao.org/faostat/en/\#data/ EK/visualize

Fernandez V (2018) Mineral commodity consumption and intensity of use re-assessed. Int Rev Financ Anal 59(2018):1-18

Fishman, R., Kishore, A., Rothler, Y., Ward, P., Jha, S., Singh, R. (2016). Can information help reduce imbalanced application of fertilizers in India? Experimental evidence from Bihar. IFPRI Discussion Paper 01517, South Asia Office, Environment and Production Technology Division, International Food Policy Research Institute (IFPRI), New Delhi, India

Fukase, E., Martin, W. (2020). Economic growth, convergence, and world food demand and supply. World Development, 132 (2020), 104954.

Gordon, C. (1998). The doubly green revolution: food for all in the twenty-first century. Ithaca, NY: Comstock Pub.

Granger C, Newbold P (1974) Spurious regressions in economics. Journal of Econometrics 2(2):111-120

Griliches Z (1958) The demand for fertilizer: an economic interpretation of a technical change. Journal of Farm Economics 40(3):591-606

Gruyter D (2020) Mineral fertilizer use in land-scarce conditions: Case of Rwanda. Open Agriculture 5(1):690-702

Gunjal K, Roberts R, Heady E (1980) Fertilizer demand functions for the five crops in the United States. South J Agric Econ 12(2):111-116

Guzmán J, Nishiyama T, Tilton J (2005) Trends in the intensity of copper use in Japan since 1960. Resour Policy 30(1):21-27

Geissler B, Mew M, Steiner G (2019) Phosphate supply security for importing countries: developments and the current situation. Sci Total Environ 677(2019):511-523

Handfield R (2012) 'The global phosphate supply market: risky and getting riskier,' supply chain view from the field. The Global Phosphate Supply Market: Risky and Getting Riskier I SCM I Supply Chain Resource Cooperative (SCRC) I North Carolina State University

Heckenmüller, M. Klepper, Narita, D., Klepper, G. (2014). Global availability of phosphorus and its implications for global food supply: an economic overview. Kiel Institute for the World Economy, Hindenburgufer 66, 24105 Kiel, Germany. https://www.files.ethz. ch/isn/175926/KWP\%201897.pdf

Horn, J., Sartorius, C. (2009). Impact of supply and demand on the price development of phosphate (fertilizer). published in: Ashley, K.; Mavinic, D. und Koch, F. (Hg.): International Conference on Nutrient Recovery from Wastewater Streams, London: IWA Publ., pp. $45-54$

Howie, P. (2006). Mineral demand - the theory in practice. In Australian Mineral Economics. Maxwell, P. Guj, P. The Australasian Institute of Mining and Metallurgy

Hsu R (1972) The demand for fertilizer in a developing country: the case of Taiwan, 1950-1966. Econ Dev Cult Change 20(2):299-309

International Fertiliser Association Statistics. (2021). Consumption. https://www.ifastat.org/databases/plant-nutrition

Jensen R, Miller N (2011) Do consumer price subsidies really improve nutrition? Rev Econ Stat 93(4):1205-1223

Johansen S (1988) Statistical analysis of cointegration vectors. J Econ Dyn Control 12(2-3):231-254

Kpadonou R, Barbier B, Owiyo T, Denton F, Rutabingwa F (2019) Manure and adoption of modern seeds in cereal-based systems in West African dry lands: linkages and (non) complementarities. Nat Res Forum 43(1):41-55
Likoya, M. and Mangisoni, J. (2006), “An estimation of fertilizer demand for smallholder farmers in Malawi", Malawi Development Exchange, Eldis Communities, Lilongwe, available at: http:// community.eldis.org/.59ee3fb9/An\%20estimation $\% 20$ of $\% 20 \mathrm{fer}$ tilizer\%20demand $\% 20$ for $\% 20$ smallholder $\% 20$ farmers $\% 20$ in $\%$ 20Malawi.pdf

Maganga, A., Mehare, A., Ngoma, K., Magombo, E. and Gondwe, P. (2011). Determinants of smallholder farmers' demand for purchased inputs in Lilongwe District, Malawi: evidence from Mitundu extension planning area. MPRA Paper No. 34590, UTC, University Library of Munich, available at: http://mpra.ub.unimuenchen.de/34590/

Mankiw N (2010) Macroeconomics, 7th edn. New York, Worth Publishers

Mankiw N. Gregory (2010). Macroeconomics, Harvard University seventh edition Worth Publishers 41 Madison Avenue New York, NY 10010.

Manning D (2015) How will minerals feed the world in 2050? Proceedings of the Geologists' Association 126(1):14-17

MAPA (2019): Rural producers are looking for bio-inputs to reduce custody of production and increase profitability. https://www.gov. br/agricultura/pt-br/assuntos/noticias/produtores-rurais-buscambioinsumos-para-reduzir-custo-da-producao-e-aumentar-renta bilidade

Matthews, E., Hammond, A. (1999). Critical consumption trends and implications - degrading earth's ecosystems. World Resources Institute: Washington

Melo P., Abdul-Salam Y., Roberts D., Gilbert A., Matthews R., Colen L., Mary S., Gomez Y., Paloma, S. (2015). Income elasticities of food demand in Africa: a meta-analysis. EUR 27650. Luxembourg (Luxembourg): Publications Office of the European Union. JRC98812. https://publications.jrc.ec.europa.eu/repository/handle/JRC98812

Mew M (2016) Phosphate rock costs, prices and resources interaction. Sci Total Environ 542:1008-1012

Mew M, Steiner G, Geissler B (2018) Phosphorus supply chain-scientific, technical, and economic foundations: a transdisciplinary orientation. Sustainability 10(4):1087

Nygards, J., Svenungsson, E. (2020). The elasticity of demand for phosphorus fertilisers in Swedish agriculture - a panel data study of price effects on phosphorus compounds in chemical fertilisers. Basic level Agricultural programme - Economics and Management Degree thesis/SLU, Department of Economics, No 1295. https://stud.epsilon.slu.se/15990/

Oxford Analytica. (2020). Moroccan phosphates sector may see virus silver lining. https://www.emerald.com/insight/content/doi/https:// doi.org/10.1108/OXAN-DB251218/full/html

Parthasarathy, N. (1994). Demand forecasting for fertilizer marketing. Food and Agriculture Organisation of the United Nations. http:// www.fao.org/3/T4240E/T4240E00.htm\#TOC

Pei F, Tilton J (1999) Consumer preferences, technological change, and the short-run income elasticity of metal demand. Resour Policy 25(2):87-109

Perloff, J. (2014). Microeconomics with calculus. Third edition ed. Harlow: Pearson Education Limited

Phillips P, Perron., P. (1988) Testing for a unit root in time series regression. Biometrica 75(2):335-344

Quddus M, Siddiqi M, Riaz M (2008) The demand for nitrogen, phosphorus and potash fertilizer nutrients in Pakistan". Pak Econ Soc Rev 46(2):101-116

Randive K, Tejashree R, Sanjeevani J (2021) An overview of the global fertilizer trends and India's position in 2020. Miner Econ 34(3):371-384

Raw Material Information System (2020). CRM list 2020. https://rmis. jrc.ec.europa.eu/?page $=$ crm-list-2020-e294f6 
Rayner A, Cooper D (1994) Cointegration analysis and the UK demand for nitrogen fertilizer. Appl Econ 26(11):1049-1054

Research and Markets. (2020). Global phosphates market analysis and outlook 2020-2027 - COVID-19 Updated - ResearchAndMarkets. com

Richardson A, Hocking P, Simpson R, George T (2009) Plant mechanisms to optimise access to soil phosphorus. Crop Pasture Sci 60(2):124-143

Ridder, M., Jong, S., Polchar, J., Lingemann, S. (2012). Risks and Opportunities in the Global Phosphate Rock Market. http://www. phosphorusplatform.eu/images/download/HCSS_17_12_12_ Phosphate.pdf

Schebek, L., Becker., B. (2014) Substitution von Rohstoffen -Rahmenbedingungen und Umsetzung. In: Kausch P, Bertau M, Gutzmer, J, Matschullat J (eds) Strategische Rohstoffe-Risikovorsorge, Berlin, Heidelberg (Springer Spektrum): 3-12)

Scholz R, Wellmer F (2013) Approaching a dynamic view on the availability of mineral resources. Glob Environ Chang 23(2013):11-27

Scholz R, Ulrich A, Eilitta M, Roy., A. (2013) Sustainable use of phosphorus: a finite resource. The Science of the Total Environment Volumes 461-462:799-803

Scot J (1964) The measurement of technology. Journal of Farm Economics 24(3):657-661

Sibe, J., Chiatchoua, C., Megne, M. (2016). The long run relationship between population growth and economic growth: a panel data analysis of 30 of the most populated countries of the world. Análisis Económico, vol. XXXI, no. 77, 2016. Universidad Autónoma Metropolitana.

Shepard. (1880). South Carolina Phosphates. A lecture delivered before the Agricultural Society of South Carolina, Charleston, South Carolina, December 12, 1879, The News and Courier Book Presses, $29 \mathrm{p}$.

Shrestha N, Raes D, Sah S (2013) Strategies to improve cereal production in the Terai region (Nepal) during dry season: simulations with aquacrop. Procedia Environ Sci 19:767-775

Skoufias E, Di Maro V, Gonzales-Cossio T, Ramirez S (2011) Food quality, calories and household income. Appl Econ 42(28):4331-4342

Sohn I (2006) Long-term projections of non-fuel minerals: we were wrong, but why? Resour Policy 30(4):259-284

Steiner G, Geissler B, Schernhammer E (2019) Hunger and obesity as symptoms of non sustainable food systems and malnutrition. Appl Sci 9(6): 1062

Stewart W, Dibb D, Johnston A, Smyth T (2005) The contribution of commercial fertilizer nutrients to food production. Agron J 97(1):1-6

Strengers, B., Vries, D, Vuuren, D. (1999). Long term perspectives on world metal use - a system dynamics model. Resources policy, 25(4,) pp. 239-255.

Stuermer, M. (2014). Industrialization and the demand for mineral commodities. Federal Reserve Bank of Dallas Research Department Working Paper 1413. https://www.bankofcanada.ca/wpcontent/uploads/2016/05/industrialization-demand-mineralcommodities.pdf
Tilman D, Balzer., C, Hill, J., Befort, B. (2011) Global food demand and the sustainable intensification of agriculture. PNAS 108(50):20260-20264

Tilton, J. (1992). Economics of the mineral industries" in Hartman HL (ed), SME mining engineering handbook, SME, Littleton.

Tirado, R., Allsopp M. (2012). Phosphorus in agriculture, problems and solutions Greenpeace Research Laboratories, Technical Report (Review)02-2002. https://www.greenpeace.to/greenpeace/ wp-content/uploads/2012/06/tirado-and-allsopp-2012-phosp horus-in-agriculture-technical-report-02-2012.pdf

Tomlinson I (2013) Doubling food production to feed the 9 billion: a critical perspective on a key discourse of food security in the UK. J Rural Stud 29(2):81-90

United Nations. (2019). World population prospects: the 2019 revision New York: United Nations.

US Geological Survey. (2021). Historical statistics for mineral and material commodities in the United States. https://www.usgs.gov/ centers/nmic/historical-statistics-mineral-and-material-commo dities-united-states\#phosphate

Van Kauwenbergh, S. (2010). World phosphate rock reserves and resources. International Fertilizer Development Center (IFDC). www.ifdc.org

Ward, P., Gupta, S., Singh, V., Ortega, D., Gautam, S., Guerena, D., Shrestha, R. (2019). What is the intrinsic value of fertilizer? Experimental value elicitation and decomposition in the Hill and Terai regions of Nepal. International Food Policy Research Institute IFPRI 745 Discussion Paper 01812, International Food Policy Research Institute, USA.

Wellmer, F. (2008) Reserves and resources of the geosphere, terms so often misunderstood. Is the life index of reserves of natural resources a guide to the future? Zeitschrift der Deutschen Gesellschaft fu" $r$ Geowissenschaften 159,pp. 575-590

Williams, G. Phosphate Outlook 2021: price rally expected to continue. https://investingnews.com/daily/resource-investing/agricultureinvesting/phosphate-investing/phosphate-outlook/

Williamson, J.M. (2010), "Does information matter? Assessing the role of information and prices in the nitrogen fertilizer management decision", 2010 annual meeting, Agricultural and Applied Economics Association No. 60892, Denver, CO, July 25-27.

World Bank. (2021). Data: browse by indicator. https://data.worldbank. org/indicator

World Health Organization. (2014). Global and regional food consumption patterns and trends. http://www.who.int/nutrition/topics

Zhou Y, Yang H, Mosler H, Abbaspour K (2010) Factors affecting farmers' decisions on fertilizer use: a case study for the Chaobai watershed in Northern China. The Journal of Sustainable Development 3(1):80-102

Publisher's note Springer Nature remains neutral with regard to jurisdictional claims in published maps and institutional affiliations. 